\title{
EFFECTS OF ROTARY SWAGING, WIRE DRAWING AND THEIR COMBINATION ON THE RESULTING PROPERTIES OF NICKEL-ALLOY WIRES
}

\author{
VPLIV ROTACIJSKEGA KOVANJA, VLEČENJA ŽICE IN \\ KOMBINACIJE OBEH POSTOPKOV NA MEHANSKE LASTNOSTI \\ NIKLJEVIH LEGIRANIH ŽIC
}

\author{
Jana Čubrová*, Kateřina Mertová, Michal Duchek \\ Metallurgical Technologies Department, COMTES FHT a.s., Průmyslová 995, 33441 Dobřany, Czech Republic \\ Prejem rokopisa - received: 2019-07-26; sprejem za objavo - accepted for publication: 2020-04-23
}

doi:10.17222/mit.2019.177

\begin{abstract}
This paper investigates the influence of drawing and rotary-swaging parameters, such as the area reduction, on the tensile properties of nickel-alloy wires. Rotary swaging and wire drawing were used to improve mechanical properties. Furthermore, the effect of the combination of these processes on the resulting hardness of the cross-sections of wires was studied. In the case of rotary swaging, the highest amount of cold deformation (an increased value of hardness) is located in the middle of the wire. This can be explained with the formation of deformation cones oriented to the centre of the wire. On the other hand, the highest amount of cold deformation in the case of drawing is located on the surface (just under the surface layer) of the drawn wires. As a result, our interest is focused on achieving large cross-sectional reductions during the wire-drawing process. In addition, the largest approach angle is used in order to avoid redundant shear. Thanks to the combination of the rotary swaging and wire drawing, there are negligible differences in the hardness across the wire diameter. The mechanical properties, the microstructures in the longitudinal and transverse directions and the hardness profiles (HV) of pure-nickel-alloy (Alloy 200) wires were compared in this investigation.
\end{abstract}

Keywords: rotary swaging, wire drawing, nickel

V članku avtorji opisujejo raziskavo vpliva tehnoloških parametrov hladnega vlečenja in rotacijskega kovanja na natezne lastnosti nikljevih legiranih žic. Oba postopka so uporabili za to, da bi izboljšali mehanske lastnosti žic. Nadalje so študirali vpliv kombinacije obeh postopkov na rezultirajočo trdoto po preseku žic. V primeru rotacijskega kovanja je prišlo do največje stopnje hladne deformacije (povečanja trdote) v sredini žice. To si razlagajo s tem, da je prišlo do tvorbe deformacijskih con orientiranih proti sredini žice. Po drugi strani pa je prišlo na hladno vlečenih žicah do največje stopnje hladne deformacije na površini žic (v plasti tik pod površino). Avtorji so želeli med vlečenjem žice doseči čim večje zmanjšanje njenega preseka. Nadalje so uporabljali največji vstopni kot, da bi se izognili pretiranim strižnim deformacijam. Z uporabo kombinacije rotacijskega kovanja in vlečenja so avtorji uspeli doseči zanemarljive razlike v trdoti po preseku žic. Med raziskavo so izvedli tudi primerjavo mehanskih lastnosti in mikrostrukture žic v vzdolžni in prečni smeri ter profile HV trdot čiste nikljeve legirane žice (Alloy 200) glede na uporabo izbranih postopkov.

Ključne besede: rotacijsko kovanje, vlečenje žice, nikelj

\section{INTRODUCTION}

Nickel and nickel-based alloys are important to the modern industry because of their ability to withstand a wide variety of severe operating conditions involving corrosive environments, high temperatures, high stresses and combinations of these factors. The corrosion resistance of pure nickel makes it particularly useful for maintaining product purity in the food industry and medicine applications. It is widely used also in general structural applications where resistance to corrosion is a prime consideration. Pure nickel is ductile and tough because it exhibits a face-centred cubic (fcc) structure. Alloy 200 is commercially pure wrought nickel $(99.5 \%)$ with a carbon content of about $0.1 \%$. This is essentially a pure metal with negligible alloying. The alloys are usu-

*Corresponding author's e-mail:

jana.cubrova@comtesfht.cz (Jana Čubrová) ally supplied in the annealed condition to give a virtually pure nickel austenite microstructure. Pure nickel has a low strength but it is a highly ductile material in the annealed condition. The strength can be increased with a work-hardening process. ${ }^{1,2}$

One way of achieving better mechanical properties is the process of rotary swaging or wire drawing. The rotary swaging is a cold forming process, incrementally reducing the cross-sectional area or otherwise changing the shape of bars, tubes or wires due to repeated radial blows. Thus, rotary swaging belongs to the suitable near-net-shape production techniques with a great potential for lightweight constructions. During a swaging process, the workpiece is fed into a swaging die in the axial direction and is initially formed in the conical entry section of the die. Radial movement and rotation of the swaging die are used..$^{3,4}$

The basic principle of a wire-drawing process is that a wire is pulled through a single opening or series of cir- 
cular openings of a drawing die. It is usually performed as a cold-working operation. Drawing is most frequently used to produce a round cross-section, but square and other shapes are also drawn. The dies are stationary. This process is used to reduce the cross-section and increase the length of a wire. Radial pressure is generated in the conical part of the drawing die by reducing of the cross-section. Deformation that occurs during the drawing operation is sometimes referred to as indirect compression. Thanks to the wire drawing, the surface quality and a perfect shape of final products are obtained. Furthermore, mechanical properties such as the strength and hardness of the wires are increased.5,6

The objectives of the present study were the investigation and comparison of the above-mentioned methods and their combination applied to commercially pure nickel alloy 200 .

\section{EXPERIMENTAL PART}

The material used to this research was commercially pure nickel alloy 200. The chemical composition of the samples can be found in Table 1. This composition was analysed with a Bruker Q4 Tasman optical emission spectrometer and a Bruker G8 Galileo gas analyser. The input diameter of the nickel rods was $7.5 \mathrm{~mm}$.

Table 1: Chemical composition of the processed material, in mass fractions $(w / \%)$

\begin{tabular}{|c|c|c|c|c|c|c|c|}
\hline Element & $\mathrm{Ni}$ & $\mathrm{Cu}$ & $\mathrm{Fe}$ & $\mathrm{Mn}$ & $\mathrm{Si}$ & $\mathrm{S}$ & $\mathrm{C}$ \\
\hline Weight $\%$ & $>99$ & $<0.25$ & $<0.40$ & $<0.35$ & $<0.35$ & $<0.01$ & $<0.15$ \\
\hline
\end{tabular}

Different deformation processes were applied to input wires. A series of experiments was performed on a recess-swaging machine and draw bench. The test material included wires with an initial diameter of $7.5 \mathrm{~mm}$ reduced to a final diameter of approximately $3 \mathrm{~mm}$. The methods used for the reduction of the diameters were rotary swaging, wire drawing and their combinations. Four options are described in this paper (Table 2).

Table 2: Specification of the experiment

\begin{tabular}{|c|l|l|}
\hline Specimen & \multicolumn{2}{|c|}{ Input / Final diameter } \\
\hline Experiment & Rotary swaging (RS) & $\begin{array}{l}\text { from 7.5 mm to 3.2 } \\
\mathrm{mm}\end{array}$ \\
\hline Experiment & $\begin{array}{l}\text { Rotary swaging } \\
\text { wire drawing }\end{array}$ & $\begin{array}{l}\text { from 7.5 mm } \\
\mathrm{mm} » 3.0 \mathrm{~mm}\end{array}$ \\
\hline Experiment & Wire drawing (WD) & $\begin{array}{l}\text { from 7.5 } \mathrm{mm} \text { to 2.9 } \\
\mathrm{mm}\end{array}$ \\
\hline Experiment & $\begin{array}{l}\text { Wire drawing » rotary } \\
\text { swaging }\end{array}$ & $\begin{array}{l}\text { from 7.5 } \mathrm{mm} \\
\mathrm{mm} » 5.0\end{array}$ \\
\hline
\end{tabular}

In the first experiment, the wire was processed in nine steps using sequential rotary swaging. The material was reduced from the initial diameter of $7.5 \mathrm{~mm}$ to a final diameter of $3.2 \mathrm{~mm}$. The total area reduction was $81 \%$. Values of area reduction per pass were 12-20\%. The rotary-swaging process was carried out in an HMP
R4-4 rotary-swaging machine. During the swaging process, the deformation of the workpiece was realized in the swaging head. Four split swaging dies were used in these experiments. The rotation speed of a swaging die can reach up to $350 \mathrm{~min}^{-1}$. During the rotary swaging, the wire moved through the swaging head and the product was taken out from the opposite side of the machine. The velocity of the wire movement was approximately $8.4 \mathrm{~m} / \mathrm{min}$.

The second experiment was carried out in a two steps, using the rotary-swaging machine and draw bench. In the first step, the wire was rotary swaged to $5.1 \mathrm{~mm}$ and subsequently drawn to a final dimension of $3.0 \mathrm{~mm}$. The whole process was done in nine steps. In this operation, the cross-sectional area was reduced by 17-20\% during each pass. The value of the total true deformation at the end of this experiment was 1.80 .

The wire-drawing process used for the third experiment was observed by means of draw-bench WMW machinery. Eight wire-drawing dies were used for the wire-drawing process. The nickel wire was reduced in the dies from the initial diameter of $7.5 \mathrm{~mm}$ to a final diameter of $2.9 \mathrm{~mm}$. The drawing speed for the nickel alloy was set to $8 \mathrm{~m} / \mathrm{min}$. In this process, the reduction from the initial to the final wire was more than $80 \%$. The reduction was evenly distributed during the passes. Nine passes through the wire dies were completed. Tungsten-carbide dies were used for the wire production.

The last experiment was focused on combining wire drawing and rotary swaging. In the first phase, the nickel wire was drawn from the initial diameter of $7.5 \mathrm{~mm}$ to a final diameter of $4.9 \mathrm{~mm}$. The area reduction per pass did not exceed $24 \%$. In the second phase, the wire was swaged to a final dimension of $3.2 \mathrm{~mm}$. The total area reduction was $81 \%$.

Table 3 shows the process parameters of rotary swaging, wire drawing and their combination, performed in order to compare the final mechanical properties and determine the effects of individual processes on the microstructure.

Table 3: Parameters of the process

\begin{tabular}{|l|c|c|}
\hline & $\begin{array}{c}\text { Area reduction } \\
(\%)\end{array}$ & $\begin{array}{c}\text { True deforma- } \\
\text { tion }(-)\end{array}$ \\
\hline 1. Experiment - RS & 81 & 1.65 \\
\hline 2. Experiment - RS »WD & 83 & 1.80 \\
\hline 3. Experiment - WD & 84 & 1.84 \\
\hline 4. Experiment - WD » RS & 81 & 1.65 \\
\hline
\end{tabular}

For the purpose of observation with a light microscope, all the samples were prepared using metallographic techniques like grinding, polishing and subsequent etching with Marble's Reagent. After the preparation, the microstructures were analysed by means of optical microscope Carl Zeiss - Observer Z1. Tensile tests were performed in an electromechanical testing machine for wires with final diameters of: $3.2 \mathrm{~mm}, 3 \mathrm{~mm}$, 
$2.99 \mathrm{~mm}$ and $3.2 \mathrm{~mm}$. The tests were executed at room temperature. The deformation was measured using a mechanical extensometer. The Vickers hardness (HV1) across the cross-section was processed by means of a Durascan 50. The aim was to compare the hardness profiles, microstructures and mechanical properties of all the samples.

\section{RESULTS}

The microstructures of the wires of nickel 200 alloy are shown in Figure 1. In these figures, the formed texture is visible along the longitudinal direction. After the swaging process, the structure becomes denser and elongated grains appear in the axial direction, as shown in Figure $1\left(1^{\text {st }}\right.$ experiment $\left.-\mathrm{RS}\right)$. This is because the material in the forging zone is subjected to the triaxle compressive stress, in which the circumferential stress is the largest. In Figure 1 ( $3^{\text {rd }}$ experiment $\left.-\mathrm{WD}\right)$, the microstructure of the drawn wire after nine drawing passes is shown. The microstructure of the drawn wire clearly shows that the morphological texture of the grains was prolonged along the wire-drawing axis. The grains after the combination of the processes $\left(2^{\text {nd }}\right.$ and $4^{\text {th }}$ experi-
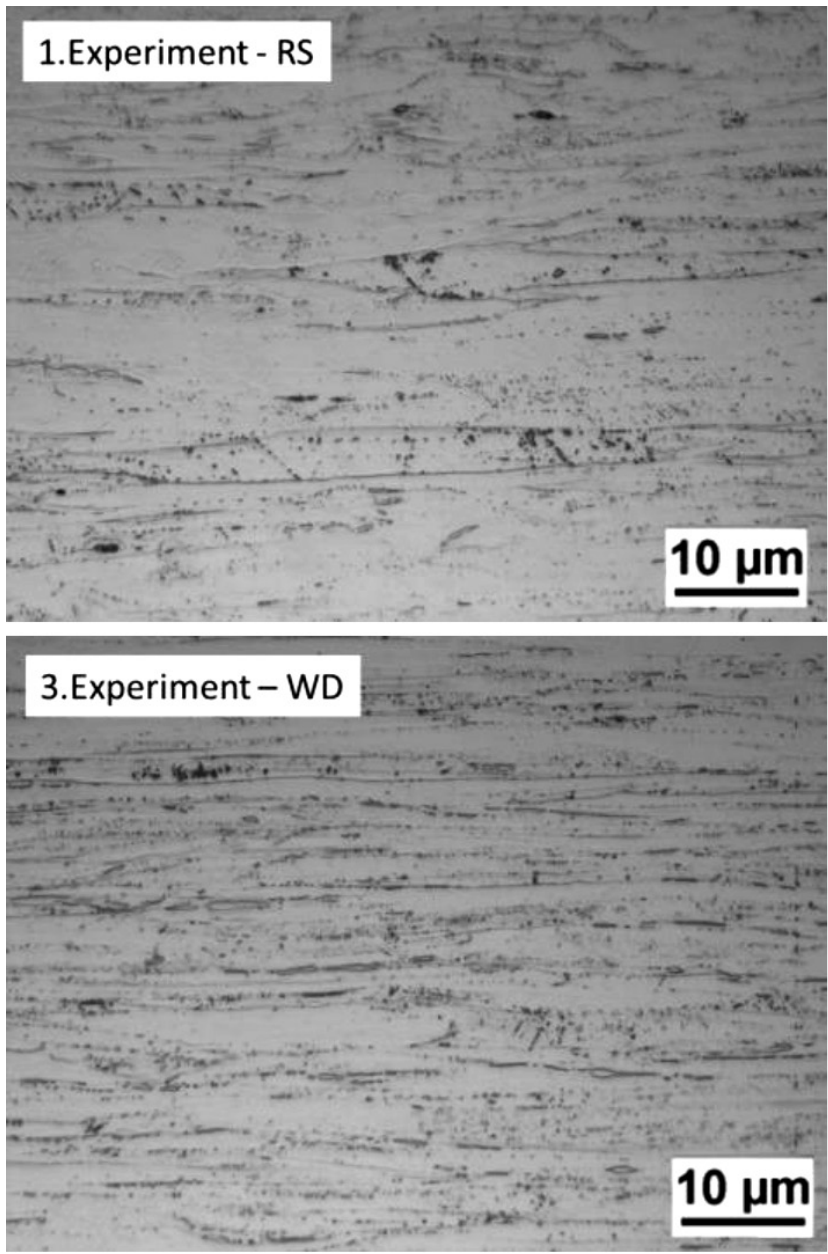

ments) were considerably stretched in the longitudinal section.

Figure 2 shows the hardness distributions through the cross-sections of the final wires. For the first experiment, it is evident that the higher amount of cold deformation (the increased value of hardness) is located in the middle of the wires. This can be explained with the formation of deformation cones oriented to the centre of the wires. The hardness values in the middle of the wires reached around $250 \mathrm{HV} 1$.

Otherwise, during the third experiment, the hardness on the surface was significantly higher than in the central part of the drawn wire thanks to the non-uniform material flow. The value of $260 \mathrm{HV} 1$ was measured on the surface, unlike the centre of the wire where the hardness was $250 \mathrm{HV} 1$.

However, the combination of rotary swaging and subsequent wire drawing led to a homogeneous distribution of hardness across the cross-section of the wire, as seen on Figure 2 ( $2^{\text {nd }}$ experiment). The differences between the surface and middle-section hardness measurements were less than $2 \%$. The fourth experiment showed that wire drawing and the subsequent rotary swaging led to the strengthening of the middle part of the wire. A high
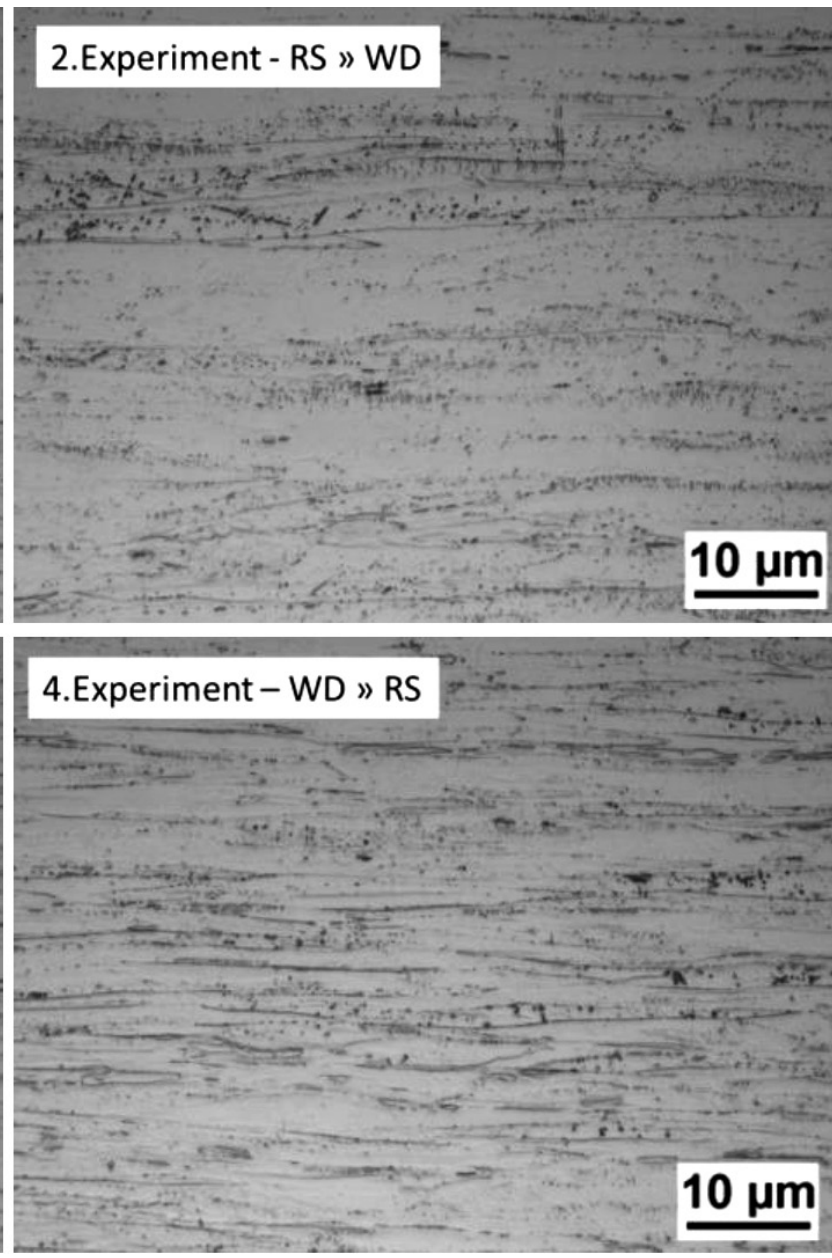

Figure 1: Micrographs of the processed wire after the final reduction step - longitudinal direction 

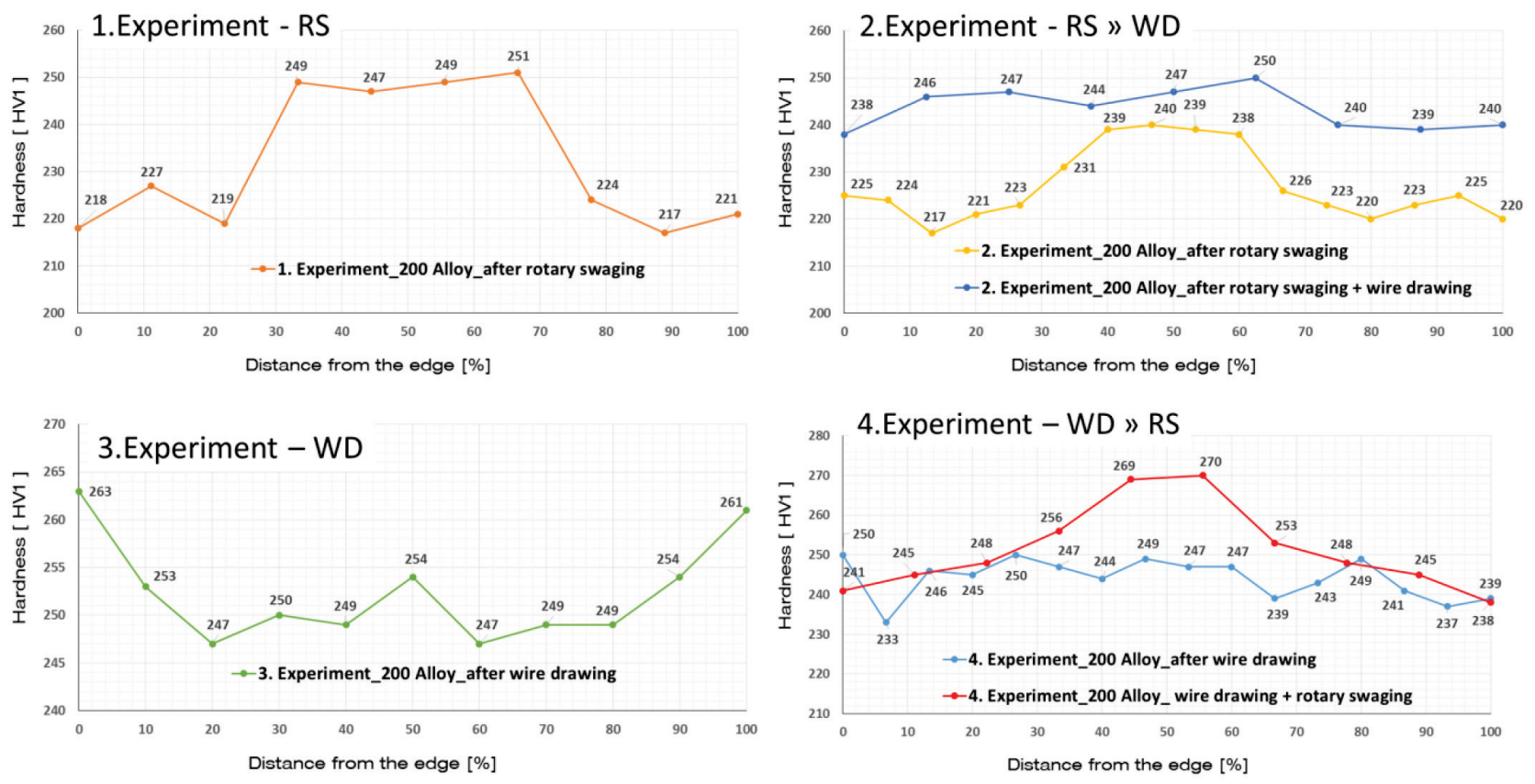

Figure 2: Hardness-profile measurements in the cross-sections of the wires

amount of hardness of around 270 HV1 was found in the middle of the wire.

A tensile test of the final diameter of the wire was performed. In Table 4, the original values of the mechanical properties of the input wires were compared with the final values of the mechanical properties for individual experiments. The tensile strength of the material increased with the increasing degree of cold-drawn deformation. The highest values of the ultimate tensile strength and offset yield strength were observed for the third experiment. Wire drawing led to an increase in the tensile strength of up to $917 \mathrm{MPa}$. It was twice as high as in the received material, while the lowest reached ductility value was $8 \%$. Thanks to this low ductility, an unstable defect could be formed in the material after the deformation. The highest value of the total elongation of $14 \%$ was measured for the rotary-swaging process.

Table 4: Mechanical properties after rotary swaging, wire drawing and combination of these methods: ultimate tensile strength (UTS); offset yield strength (OYS); reduction in area (RA); total elongation (El)

\begin{tabular}{|l|c|c|c|c|}
\hline \multicolumn{1}{|c|}{ Condition } & $\begin{array}{c}\text { UTS } \\
(\mathrm{MPa})\end{array}$ & $\begin{array}{c}0.2 \mathrm{OYS} \\
(\mathrm{MPa})\end{array}$ & $\begin{array}{c}\text { El } \\
(\%)\end{array}$ & $\begin{array}{c}\text { RA } \\
(\%)\end{array}$ \\
\hline As received & 462 & 148 & 46 & - \\
\hline Rotary swaging & $763 \pm 3.8$ & $753 \pm 7.3$ & $14 \pm 0.9$ & $75 \pm 2.0$ \\
\hline $\begin{array}{l}\text { Rotary swaging } \\
\text { wire drawing }\end{array}$ & $850 \pm 3.1$ & $834 \pm 5.3$ & $11 \pm 0.3$ & $68 \pm 1.5$ \\
\hline Wire drawing & $917 \pm 4.9$ & $909 \pm 0.5$ & $8 \pm 0.8$ & $62 \pm 2.0$ \\
\hline $\begin{array}{l}\text { Wire drawing } \text { " ro- } \\
\text { tary swaging }\end{array}$ & $823 \pm 6.8$ & $814 \pm 2.2$ & $13 \pm 2.1$ & $68 \pm 1.2$ \\
\hline
\end{tabular}

Rotary swaging led to an increase in the ultimate tensile strength of $763 \mathrm{MPa}$. In the second experiment, the combination of rotary swaging and subsequent wire drawing reached an ultimate tensile strength of $850 \mathrm{MPa}$ with a total elongation of $11 \%$. The second experiment offers a good compromise between strength and ductility. Unfortunately, these techniques show a uniform homogeneous distribution of hardness across the cross-section.

\section{DISCUSSION}

The yield strength of the material was observed to reduce with increasing degree of cold-drawing, an indication of reduction in the ductility and the tensile strength of the material reduced with increasing degree of cold-drawn deformation. The ability of the material to resist impact loads when nails are hammered reduced with increasing degree of drawn deformation as a result of strain

hardening of the material after the drawing operation. However the resilience of the material to further cold drawn deformation increased with increasing degree of deformation as evident in the Brinnel hardness number which increases with the degree of drawing deformation. This is an indication of the material's approach to brittleness as the degree of drawn deformation increases The yield strength of the material was observed to reduce with increasing degree of cold-drawing, an indication of reduction in the ductility and the tensile strength of the material reduced with increasing degree of cold-drawn deformation. The ability of the material to resist impact loads when nails are hammered reduced with increasing degree of drawn deformation as a result of strain hardening of the material after the drawing operation. However 
the resilience of the material to further cold drawn deformation increased with increasing degree of deformation as evident in the Brinnel hardness number which increases with the degree of drawing deformation. This is an indication of the material's approach to brittleness as the degree of drawn deformation increases.

The yield strength of the material was observed to reduce with increasing degree of cold-drawing, an indication of reduction in the ductility and the tensile strength of the material reduced with increasing degree of cold-drawn deformation. The ability of the material to resist impact loads when nails are hammered reduced with increasing degree of drawn deformation as a result of strain hardening of the material after the drawing operation. However the resilience of the material to further cold drawn deformation increased with increasing degree of deformation as evident in the Brinnel hardness number which increases with the degree of drawing deformation. This is an indication of the material's approach to brittleness as the degree of drawn deformation increases

The influence of individual processing methods on the final properties of wires were shown with the performed experiments. It became evident how the rotary-swaging and wire-drawing processes affect the development of a microstructure. The microstructure in the longitudinal section of all the tested samples showed grain elongation along the longitudinal axis with a reduced grain size due to cold deformation.

Furthermore, the influence of individual methods on the hardness profile was investigated. The measured values correspond to the hardness distribution described in the article, written by H. P. Stuwe. ${ }^{7}$ In this article, it was mentioned that if the rotation angle is different, as is the case with conventional commercial devices, the strain path for each stroke varies irregularly. Kinetic softening very nearly prevents work hardening in the outer layer of a wire and even the centre of the wire work-hardens much less than the drawn wire. This thesis was confirmed with the first experiment. The opposite is true of a drawn wire. The core of a rod is work-hardened by the unidirectional strain. The outer layers are work-hardened somewhat more by an additional shear force. The homogeneous hardness distribution in the sample across the cross-section was achieved with a combination of rotary swaging and subsequent wire drawing. The ultimate tensile strengths for all the variations ranged from $760 \mathrm{MPa}$ to $910 \mathrm{MPa}$. In the literature, the breaking strength was increased $^{2}$ by cold rolling up to $760 \mathrm{MPa}$ and the elongation was $8 \%$. In our case, the strength was $917 \mathrm{MPa}$ at the same elongation value.

The finished-product quality is strongly dependent on the hardness distribution, mechanical strength and microstructure. That is why investigations of different options of cold-hardening processes are important. The article, presented in the Journal of Material Research and Technology by J. Zottis, ${ }^{8}$ discusses the application of the experimental and numerical methods, based on the hard- ness measurement, which allows evaluation of the distribution of strain and mechanical properties in a drawn product. The author of this article concluded that the calculated hardness values showed good correlation with the experimentally measured microhardness values for a cold-drawn product. Therefore, the opposite method can be explored, i.e., the measurement of hardness distribution for a cold-drawn material can be used for calculating strain distributions, correlating them with the numerical simulation results. All of the knowledge obtained with the performed experiments can be contributed to the technological improvement. The experimental values serve as the data used for a comparison with the FEM model simulation of wire drawing, rotary swaging and the combination of these processes.

\section{CONCLUSIONS}

This paper describes a successful processing of commercially pure nickel 200 alloy using the rotary-swaging and wire-drawing techniques with the goal of improving mechanical properties and obtaining homogenous hardness across the cross-section of a wire. The total area reduction was roughly $80 \%$ for all the processes. Vickershardness measurements and tensile tests were performed. Microstructures were also observed. The main conclusions are summarized as follows:

Rotary swaging and wire drawing further reduced the average grain size. Grains were preferentially elongated in the longitudinal direction and the sample had a very intense fibre texture oriented parallel to the longitudinal direction.

Nine passes through the rotary-swaging dies led to a strength of $763 \mathrm{MPa}$ and a yield stress of $753 \mathrm{MPa}$, with a decrease in the elongation. In the rotary-swaging process, there was a significant difference between the surface hardness and the hardness measured at the centre of the wire. The surface hardness was, on average, $25 \mathrm{HV} 1$ lower than the hardness in the middle of the wire.

A high strengthening effect on each wire was observed. The highest ultimate strength for the wire-drawing process was $917 \mathrm{MPa}$, with a true deformation of 1.84. This increase was mainly due to the refinement of the initial grain structure and an increased dislocation density. The total elongation dropped below $10 \%$ during this process. In the case of wire drawing, the course of hardening was opposite to that of rotary swaging. The largest value was found on the wire surface. The surface hardness was, on average, $10 \mathrm{HV} 1$ higher than the hardness in the middle of the wire.

The used combination of rotary swaging and subsequent wire drawing resulted in a homogenous hardness distribution across the cross-section. The ultimate strength was $850 \mathrm{MPa}$. The increase was mainly due to the refinement of the initial grain structure. This processing of the wire led to a compromise between good strength and toughness of a nickel wire. 


\section{J. ČUBROVÁ et al.: EFFECTS OF ROTARY SWAGING, WIRE DRAWING AND THEIR COMBINATION ...}

\section{Acknowledgment}

This paper was created under the project Development of West-Bohemian Centre of Materials and Metallurgy, No. LO1412, financed by the Ministry of Education of the Czech Republic.

\section{REFERENCES}

${ }^{1}$ J. C. M. Farrar, The alloy tree, A guide to low-alloy steels, stainless steels and nickel-base alloys, Woodhead Publishing Ltd, Cambridge, 2004, 164-165

${ }^{2}$ J. R. Davis, ASM specialty handbook: nickel, cobalt, and their alloys, ASM International, Ohio, 2000, 14-20

${ }^{3}$ B. Fluth, D. Hack, A. L. Hoffmanner, R. Kell, W. Perun, ASM Handbook, Metalworking: Bulk Forming, Rotary Swaging of Bars and Tubes, 14A, 2005, 156-171, doi:10.31399/asm.hb.v14a. 9781627081856
${ }^{4}$ M. Duchek, J. Palán, T. Kubina, mechanical and microstructural properties of rotary-swaged wire of commercial-purity titanium, International Journal of Chemical, Materials and Biomolecular Sciences, 13 (2019) 7

${ }^{5}$ N. Liu, Theses: Microstructure and mechanical properties of cold drawn steel wires, Cowan University, 2012, https://ro.ecu.edu.au/theses/512, 4.7.2019

${ }^{6}$ R. N. Wright, Wire Technology, Process Engineering and Metallurgy, 2nd ed., Elsevier, Oxford 2016, 177-200

${ }^{7}$ H. P. Stuwe, Equivalent strains in severe plastic deformation, Advanced Engineering Materials, 5 (2003) 5, 291-295, doi:10.1002/ adem.200310085

${ }^{8}$ J. Zottis, C. A. T. S. Diehl, A. S. Rocha, Evaluation of experimentally observed asymmetric distributions of hardness, strain and residual stress in cold drawn bars by FEM-simulation, Journal of Materials Research and Technology, 7 (2018) 4, 469-478, doi:10.1016/ j.jmrt.2018.01.004 